\title{
An Investigation on the Millennials' Use of Web Technologies in Higher Education
}

\author{
Faizah Abd Majid, Sharifah Muzlia Syed Mustafa, \\ Wan Nurul Elia Haslee Shahril, Kaarthiyainy Subramaniam
}

\author{
Faculty of Education, \\ Universiti Teknologi MARA, Kampus Puncak Alam, Bandar Puncak Alam 42300, Selangor, Malaysia \\ faiza404@uitm.edu.my, muzlia@uitm.edu.my, nurulelia@uitm.edu.my, kaarthiyainy@uitm.edu.my \\ Tel: +60162384774
}

\begin{abstract}
There is a growing number of millennials in higher education. Much literature has confirmed the millennials as web technology-savvy. This study intended to explore their use of web technologies in higher education learning. The researchers administered a student survey to 646 undergraduates studying in social sciences faculties in nine Malaysian public universities. The respondents confirmed past findings on their use of web technologies. The present study further confirmed that the millennials need training on digital literacy to develop their equal strength as users of web technologies for social and entertainment as well as for academic purposes alike.
\end{abstract}

Keywords: Millennials, web technologies, higher education learning

eISSN: 2398-4287 @ 2019. The Authors. Published for AMER ABRA cE-Bs by e-International Publishing House, Ltd., UK. This is an open access article under the CC BYNC-ND license (http://creativecommons.org/licenses/by-nc-nd/4.0). Peer-review under responsibility of AMER (Association of Malaysian Environment-Behaviour Researchers), ABRA (Association of Behavioural Researchers on Asians) and cE-Bs (Centre for Environment-Behaviour Studies), Faculty of Architecture, Planning \& Surveying, Universiti Teknologi MARA, Malaysia.

DOI: https://doi.org/10.21834/e-bpj.v4i12.1889

\subsection{Introduction}

Issues about the millennials and how they use web technologies in higher education became the central focus of this study. Now that 21st- century education becomes a norm in most higher education institutions, many academics and students alike are rushed into the idea without clear and much understanding of what 21 st-century education could entail. Higher education institutes are quick to assume that the integration of web technologies in the curriculum, especially in the teaching and learning delivery are the indicators of the way forward in 21st-century education. However, not much is known about the higher education students' preferences in using web technologies in learning. The understanding and uses of web technologies in higher education between the academics who are digital immigrants and their millennial students, also known as digital natives, may need to be confirmed.

This study in specific explored the millennials' perceptions of the web technologies in higher education. The millennials' web technologies experiences, how they accessed for information, processed and assessed the information via the web technologies were investigated in this study. To this end, the term 'web technologies' refers to the development of a mechanism that allows two or more computers to communicate over a network (Internet); it also refers to web sites and applications that allow one to create and share material and information online (Khan, 2007). In the present study, podcasting and content hosting services and websites such as Wikipedia, YouTube, Facebook, MySpace, Flickr are examples of web technologies. The primary purpose of the study was to confirm how the millennials who were undergraduate students perceived web technologies in higher education learning. The findings are

eISSN: 2398-4287 @ 2019. The Authors. Published for AMER ABRA cE-Bs by e-International Publishing House, Ltd., UK. This is an open access article under the CC BYNC-ND license (http://creativecommons.org/licenses/by-nc-nd/4.0/). Peer-review under responsibility of AMER (Association of Malaysian Environment-Behaviour Researchers), ABRA (Association of Behavioural Researchers on Asians) and cE-Bs (Centre for Environment-Behaviour Studies), Faculty of Architecture, Planning \& Surveying, Universiti Teknologi MARA, Malaysia. DOI: https://doi.org/10.21834/e-bpj.v4i12.1889 
expected to shed some light on how web technologies could be integrated into higher education learning. The academics in specific could use the findings in confirming how best they could suit their millennial students' learning needs.

\subsection{Literature Review}

\section{Millennials and higher education}

'Millennials' is the latest generation we are interfacing within higher education. As a generational cohort, the millennials show several characteristics and preferences different from the generations before them. Millennials are noticeably self-confident, optimistic, multitasking, and more independent than their previous generation (Howe and Strauss, 2000). Their experiences, values, and preferences would likely shape a different world and challenge old paradigms. The works of McGhee (2006) and Prensky (2005) are among the earliest documented in confirming the potential influence of millennials' characteristics and preferences on higher education.

There are also other terms referring to the millennials. Interestingly, the list mostly connects the millennials to technology. The relevant terms include Digital natives, Native speakers, Nets, Internet generation, iGeneration, and Nintendo digital generation. The emphasis on technology-savvy and internet is quite apparent in all the listed terms indicating the millennials' close connection with the digital world.

Howe and Strauss (2000) affirmed that the millennial generation had already started entering college in 2000. Thus, it becomes relevant, given their particular characteristics, to address the challenges the millennials pose to higher education. Matney (2006) stated that the millennials would shape the future of higher education based on their unique characteristics. This, in turn, provides potential differences in views on the learning process between them and their lecturers who would almost all come from a different generation. Millennials are also known as digital natives who consider technology as a part of life and a basic necessity for their survival. Their lecturers on the other hand, who generally are either Generation X or baby boomers, are also known as digital immigrants. Hence, it is quite easy to understand the possibility of differences in their views on the use of web technologies in higher education learning. Arora, Agarwal, and Kumar (2018) and Abbol (2019) commented that the millennials are avid internet users and most of their lifestyle depends on the internet.

Matney (2006) and Baker Rosa and Hastings (2018) further claim that it is not only their characteristics that make it a challenge, but the dynamics, the characteristics and experiences of the previous generations when interacting with them create the greatest challenge. The gap between the millennials and previous generations is more significant than the gap between the baby-boomers and Genexers. One of the main causes is the vertiginous pace of technological development and change that creates a divide embodied in the millennial generation. Leblanc and Gensler (2018) and Thompson (2019) stated that the internet and web technologies have impacted the millennials in various ways including how they interact and communicate. Therefore, it is this latest cohort of higher education students that would lead to new demands in changing the classrooms, approaches, and resources for learning.

\subsection{Methodology}

The present study is a part of a bigger research that employed a mixed-method research design. However, the paper discusses a part of the bigger study, which focused on the quantitative data obtained through a student survey.

In determining the samples, the research utilized a cluster sampling technique. The target population of this study was undergraduate students of social sciences faculties in Malaysian public universities. Altogether, a total of 9 public universities offering Social Sciences programs were selected for data collection. From the nine participating universities, a total of 646 respondents took part in the present study.

A student survey was distributed to the respondents. There were two sections in the questionnaire; Part A is on Demographic Information, and Part B elicits the respondents' perceptions of the integration of technology in their higher education learning experience. Specifically, there were four constructs involved in Part B namely; Experience with technology, Accessing Information, Processing Information, and Assessing Information. Table 1 below summarizes the information about the questionnaire and the Cronbach Alpha values for each construct of the questionnaire.

Table 1: Cronbach Alpha values

\begin{tabular}{|c|c|c|c|}
\hline Part & Category & Number of items & Cronbach \\
\hline \multirow[t]{5}{*}{ B } & $\begin{array}{l}\text { Demographic information } \\
\text { Integration of technology }\end{array}$ & 10 & \\
\hline & - Experience with technology. & 6 & .826 \\
\hline & - Accessing information & 10 & .670 \\
\hline & - $\quad$ Processing information & 18 & .878 \\
\hline & - Assessing information & 7 & .841 \\
\hline
\end{tabular}




\subsection{Findings}

A total of 646 respondents participated in this study comprising female students who formed the majority $(71.3 \%, n=460)$ and male students who formed $28.7 \%$ ( $n=186)$ of the total respondents. A large number of the respondents were Malay (87.9\%), followed by $5.3 \%$ Chinese, $3.4 \%$ Indian, and $4.2 \%$ of other races.

The demographic profiles of the respondents were elaborated in the discussion on the samples above. However, it is essential to note that the respondents came from various public universities in Malaysia, taking up Social Sciences courses as further detailed in Table 2.

Table 2: Demographic Profiles of Students

\begin{tabular}{|c|c|c|c|}
\hline & & Frequency & Percent \\
\hline \multirow[t]{3}{*}{ Gender } & Male & 186 & 28.7 \\
\hline & Female & 460 & 71.3 \\
\hline & Total & 646 & 100.0 \\
\hline \multirow[t]{3}{*}{ Age } & 24 and below & 559 & 86.5 \\
\hline & 25 and above & 87 & 13.5 \\
\hline & Total & 646 & 100 \\
\hline \multirow[t]{5}{*}{ Race } & Malay & 563 & 87.2 \\
\hline & Chinese & 34 & 5.3 \\
\hline & Indian & 22 & 3.4 \\
\hline & Others & 27 & 4.2 \\
\hline & Total & 646 & 100 \\
\hline \multirow[t]{19}{*}{ University } & Universiti Malaya (UM) & 77 & 11.9 \\
\hline & Universiti Teknologi Malaysia (UTM) & 100 & 15.4 \\
\hline & Universiti Kebangsaan Malaysia (UKM) & 49 & 7.6 \\
\hline & Universiti Putra Malaysia (UPM) & 69 & 10.6 \\
\hline & Universiti Teknologi MARA (UiTM) & 291 & 44.9 \\
\hline & International Islamic University Malaysia (IIUM) & 20 & 3.4 \\
\hline & Universiti Malaysia Sarawak (UNIMAS) & 40 & 6.2 \\
\hline & Total & 646 & 100.0 \\
\hline & Education & 293 & 45.2 \\
\hline & Communication and Media Studies & 52 & 8.0 \\
\hline & Art and Design & 145 & 22.4 \\
\hline & Law & 81 & 12.5 \\
\hline & Arts and Social Science & 75 & 11.9 \\
\hline & Total & 646 & 100.0 \\
\hline & Semester 5 & 220 & 34.1 \\
\hline & Semester 6 & 82 & 12.7 \\
\hline & Semester 7 & 289 & 44.7 \\
\hline & Semester 8 & 55 & 8.5 \\
\hline & Total & 646 & 100.0 \\
\hline
\end{tabular}

In attempting to investigate how the selected millennials used web technologies in higher education, four aspects of learning were identified: experience with technology, accessing information, processing information, and assessing information. The respondents' responses were elicited using a Likert scale 1 (strongly disagree) to 4 (strongly agree). The following are the discussions.

\subsection{Experience with technology}

The respondents strongly agreed with all six items regarding their experience with technology. As signified in Table 4 below, the respondents claimed to have access to technology (computer, smartphone, tablet) (mean $=3.59$ ), use the internet for academic purposes (completing assignments \& projects) (mean $=3.44$ ), always be connected to the internet (mean $=3.42$ ); spend a lot of time using the technology (mean $=3.25$ ), use the internet for entertainment (social networking \& games) (mean $=3.15)$, and spend a lot of time surfing the internet (mean $=3.15$ ). Based on the high mean scores across the items, it could be inferred that the respondents had relevant experiences with technology either for social and entertainment purposes or for academic purposes.

Table 3: Descriptive for Millenials' Experience with Technology

\begin{tabular}{|c|c|c|c|}
\hline & $\mathrm{N}$ & Mean & S.D. \\
\hline I have access to technology (computer, smartphone, tablet). & 647 & 3.59 & 0.60 \\
\hline I use the internet for academic purposes (completing assignments \& projects). & 646 & 3.44 & 0.67 \\
\hline I am always connected to the internet. & 645 & 3.42 & 0.70 \\
\hline I spend a lot of time using technology. & 643 & 3.25 & 0.76 \\
\hline I use the internet for entertainment (social networking \& games). & 646 & 3.15 & 0.79 \\
\hline
\end{tabular}




\begin{tabular}{|lrr}
\hline I spend a lot of time surfing the internet. & 642 & 3.15 \\
\hline
\end{tabular}

\subsection{Accessing information}

In terms of accessing information, the respondents agreed that they did six of the activities listed. They were aware of the various search engines available (Google, Bing, Yahoo) (mean $=3.53$ ), used online sources (e-books, online journals, websites) to complete their assignments (mean $=3.39$ ), held online discussion (email, chat, forum, WhatsApp) with their peers (mean $=3.35$ ), relied on online sources (e-books, online journals, websites) to get information for assignments/projects (mean $=3.28$ ), held face-to-face discussion with their peers (mean $=3.24$ ), and read books to get information for assignments/projects (mean $=3.03$ ).

Interestingly, the respondents claimed that they did not rely on their lecturers' instructions (mean $=2.96$ ), their lecturers' notes (mean $=2.77$ ), did not spend time at the library to search for materials (mean $=2.47$ ), and did not ask their lecturers for information (mean $=2.13$ ). Table 5 below provides a summary of the relevant findings.

The findings had yielded information related to how the millennials accessed information in higher education. It could be concluded that they relied heavily on the various web technologies to access information with little reliance on their lecturers and the facilities such as the library and its book collection.

Table 4: Descriptive for Millenials' Accessing Information

\begin{tabular}{|c|c|c|c|}
\hline & $\mathrm{N}$ & Mean & S.D. \\
\hline I am aware of the various search engines available (Google, Bing, Yahoo). & 650 & 3.53 & 0.61 \\
\hline I use online sources (e-books, online journals, websites) to complete my assignments. & 649 & 3.39 & 0.66 \\
\hline I hold online discussions (email, chat, forum, WhatsApp) with my peers. & 538 & 3.35 & 0.77 \\
\hline I rely on online sources (e-books, online journals, websites) to get information for assignments/projects. & 649 & 3.28 & 0.66 \\
\hline I hold non-face-to-face discussion with my peers. & 650 & 3.24 & 0.69 \\
\hline I read books to get information for assignments/projects. & 646 & 3.03 & 0.78 \\
\hline I rely on my lecturers' instructions. & 565 & 2.96 & 0.80 \\
\hline I rely on my lecturers' notes. & 650 & 2.77 & 0.88 \\
\hline I spend time at the library to search for materials. & 649 & 2.47 & 0.93 \\
\hline I ask my lecturers for information. & 650 & 2.13 & 0.94 \\
\hline
\end{tabular}

\subsection{Processing information}

In terms of processing information, the millennials claimed to do many of the activities listed. The most frequent activities they did were confirming their understanding by asking peers ( $m e a n=3.28$ ), looking for the main ideas as they read (mean $=3.26$ ), summarizing the notes into their own words for better understanding (mean $=3.24)$, browsing the headings, pictures or charts $(m e a n=3.22$ ) and looking for familiar concepts and ideas that spark their interests as they read (mean $=3.20)$.

Nonetheless, there were more items rated low by the respondents. The three activities they did the least were rereading and rewriting their notes (mean $=2.95$ ), taking notes as they read (mean $=2.94$ ) and using online exercises to enhance their knowledge (mean $=2.72$ ). In relating to the use of web technologies, it is observed that the millennials in the study did not explore the opportunities web technologies could provide, such as doing online quizzes. Table 6 below summarizes the findings.

Table 5: Descriptive for Millenials' Processing Information

\begin{tabular}{|c|c|c|c|}
\hline & $\mathrm{N}$ & Mean & S.D. \\
\hline I confirm my understanding by asking my peers. & 646 & 3.28 & 0.64 \\
\hline I look for the main ideas as I read. & 648 & 3.26 & 0.67 \\
\hline I summarize my notes into my own words, for better understanding. & 645 & 3.24 & 0.71 \\
\hline & 649 & 3.22 & 0.71 \\
\hline I look for familiar concepts as well as ideas that spark my interest as I read. & 650 & 3.20 & 0.65 \\
\hline & 647 & 3.16 & 0.69 \\
\hline I take notes during class lectures. & 648 & 3.15 & 0.76 \\
\hline I depend on online tools (Google Translate, Dictionary.com) for better understanding of new words. & 647 & 3.14 & 0.76 \\
\hline I search for the meaning of new words as soon as I see them. & 649 & 3.14 & 0.78 \\
\hline I question myself regarding the content before, during, and after reading. & 650 & 3.11 & 0.72 \\
\hline I try to organize main ideas and details into a meaningful method. & 646 & 3.08 & 0.69 \\
\hline I say difficult concepts out loud to understand them better. & 646 & 2.99 & 0.83 \\
\hline I quiz myself over materials that I read. & 647 & 2.98 & 0.79 \\
\hline I confirm my understanding by asking my lecturers. & 647 & 2.97 & 0.79 \\
\hline I reread and rewrite my notes. & 649 & 2.95 & 0.86 \\
\hline I take notes as I read. & 650 & 2.94 & 0.85 \\
\hline I use online exercises to enhance my knowledge. & 647 & 2.72 & 0.92 \\
\hline I compare my notes with my classmates. & 650 & 2.55 & 0.98 \\
\hline
\end{tabular}

\subsection{Assessing information}

In terms of assessing information, the millennials used online sources only to enhance their learning abilities (mean $=3.32$ ). 
They seem not to check their work using online tools (e.g. Turnltln) (mean $=2.80)$, trust the information accessed via websites (mean $=2.80)$, trust the information accessed via open-source internet (e.g. Wikipedia) (mean = 2.62), and trust the information accessed via social network (mean $=2.51$ ).

Additionally, the respondents did not put up their work online for review (mean $=2.32$ ), and they did not share their work by making it available online (mean $=2.31$ ). Table 7 below signifies the findings.

Table 6: Descriptive for Millenials' Web Assessing Information

\begin{tabular}{|c|c|c|c|}
\hline & $\mathrm{N}$ & Mean & S.D. \\
\hline Online sources enhance my learning abilities. & 648 & 3.32 & 0.65 \\
\hline I check my work using online tools (e.g. Turnltln). & 648 & 2.80 & 0.95 \\
\hline I trust the information accessed via websites. & 647 & 2.80 & 0.82 \\
\hline I trust the information accessed via open source internet (e.g. Wikipedia). & 648 & 2.62 & 0.89 \\
\hline I trust the information accessed via the social network. & 647 & 2.51 & 0.91 \\
\hline I put up my work online for review. & 646 & 2.32 & 1.02 \\
\hline I share my work by making it available online. & 646 & 2.31 & 1.01 \\
\hline
\end{tabular}

\subsection{Discussion}

To this end, it could be observed and deduced that the responses had indicated their familiarity and experiences with web technologies. However, they were prone to use web technologies for social and entertainment purposes than for academic purposes. This finding confirms past research findings as claiming millennials are indeed technology-savvy and prone to use the internet more for social and entertainment than for academic purposes (Arora et al., 2018; Leblanc \& Gensler, 2018; Abbol, 2019). Additionally, though the respondents in the present study could access the information via the relevant web technologies, they still lacked the opportunities to depend on web technologies to access information. Similarly, the respondents did not seem to assess the information and their academic work through web technologies. In other words, although the millennials might know how to obtain information, they might not know how to assess the credibility of web sources and also to use web technologies to assess their academic work. These findings further affirm past research findings that claim although the millennials are digital natives, they lack the skills in using the web technologies for academic purposes such as assessing for academic information and assessing the information obtained from web technologies (Thompson, 2019; McGhee, 2006; Prensky, 2005).

\subsection{Conclusion}

This study attempted to confirm the use of web technologies among the millennials as undergraduates in the selected Malaysian public universities. Besides their overall experiences with web technologies, the study explored the millennials' perceptions of their web technologies uses in their higher education learning involving how they accessed, processed, and assessed information for academic purposes. The salient findings include the confirmation of past research findings, which generally claim that millennials are, technologysavvy and live with the internet as a necessary survival item. Nonetheless, the millennials still need further exposure in using web technologies for academic purposes as there are instances that suggest the millennials lack digital literacy skills such as accessing for and assessing the information available online for academic purposes. To this end, much could still be explored in terms of the higher education curriculum and teaching and learning that support digital literacy growth among the millennials. Further research could be conducted on the learning behaviors of the millennials and how web technology could facilitate their learning process. One is of potential research also includes the need to develop training modules that nurture the millennials' skill set in using web technology as one of their learning tools.

\section{Acknowledgements}

The research team would like to thank the Ministry of Higher Education for the full funding of this research through FRGS (FRGS/2/2013/SSI09/UITM/02/1). Special thanks are also extended to the Institute of Research Management and Innovation (IRMI), UiTM. Most importantly, our deepest gratitude goes to the respondents who comprised millennials from the selected faculties in various Malaysian public universities.

\section{References}

Abbot, L. (2019). Eleven millennials' traits you should know before you hire them. Retrived from:

https://business.linkedin.com/talent-solutions/blog/2013/12/8-millennials-traits-you-should-know-about-before- you-hire-them

Arrora, T. Agarwal, B., and Kumar, A. (2018). A study of millennials' preferences for social media advertising in Delhi NCR. In Indian Journal of Marketing. Vol 48(10). Doi: 10-19010/ijom/2018/v48/i10/132334 
Baker Rosa, N., and Hastings, S. (2018). Managing millennials: Looking beyond generational stereotypes. In Journal of Organizational Change Management. Vol 31 (4). pp. 920-930. https://doi.org/10.1108/JOCM-10-2015-0193

Howe, N. \& Strauss, B. (2000). Millennials Rising: The Next Great Generation. New York: Vintage Books.

Khan, B. H. (Ed.). (2007). Flexible learning in an information society. Hershey, PA: Information Science Publishing.

Leblanc, W., and Gensler, A.D. (2018). Understanding the preferences of millennials: Implications for Chicago Suburbs. In Illinois Municipal Policy Journal. Vol 3(1). pp $1-16$.

Matney, M. M. (2006). "What Is Emerging in Research about Millennials?" What's on Our Student's Minds, 2 (3).

McGhee, Tom. (2006) Millennials make their mark. The Denver Post.

Prensky, Marc. (2005). Digital Natives, Digital Immigrants. On the Horizon. 9 (5).

Thompson, K.S.(2013). Organizational learning support preferences of millennials: an interpretive study. A PhD Thesis. University of Connecticut 